\title{
Uncovering the gaps in the provision of services in the rural Okhahlamba Municipality of KwaZulu-Natal province
}

\begin{abstract}
Authors:
Hlengiwe Mabizela ${ }^{1}$ (1)

Noluthando S. Matsiliza ${ }^{1}$

Affiliations:

${ }^{1}$ Department of Public Management, Economics and Law, Faculty of Management Sciences, Durban University of Technology, Pietermaritzburg, South Africa
\end{abstract}

Corresponding author: Noluthando Matsiliza, thandimatsi@yahoo.co.za

Dates:

Received: 28 Feb. 2020

Accepted: 15 Oct. 2020

Published: 21 Dec. 2020

How to cite this article: Mabizela, H. \& Matsiliza, N.S., 2020, 'Uncovering the gaps in the provision of services in the rural Okhahlamba Municipality of KwaZulu-Natal province', Africa's Public Service Delivery and Performance Review 8(1), a390. https:// doi.org/10.4102/apsdpr. v8i1.390

\section{Copyright:}

(C) 2020. The Authors.

Licensee: AOSIS. This work is licensed under the

Creative Commons

Attribution License.

Read online:

Scan this $Q R$ code with your smart phone or mobile device to read online.
Background: Despite the policies and guidelines supporting service provision at Okhahlamba, the municipality is experiencing a backlog in service delivery. The dissatisfaction of community members at Ukhahlamba indicates that there is a moral disengagement between them and the municipal officials.

Aim: The aim of this study is to examine gaps in service delivery at Okhahlamba Municipality. The intention of this study is to determine the strategies that can enhance municipal capacity and successfully provide basic services. A case study design was adopted to conduct this study.

Setting: The study was conducted at Ukhahlamba District municipality. The respondents included municipal officials, staff from the Ministry of Rural Development and Agriculture, community members and experts.

Methods: Data was collected using a mixed methodology. A purposive sample was drawn from a population of communities in Okhahlamba and Maswazini, and unstructured interviews and questionnaires were used to collect data and a thematic approach was followed to analyse the data including the use of the Statistical Package for Social Sciences (SPSS) software version 25.0.

Results: It was found that Okhahlamba Municipality is experiencing numerous challenges that stifle progress in as far as the provision of services is concerned, due to challenges related its capacity and resource management.

Conclusion: This study revealed that the municipality is not complying with various policies that mandate them to provide basic services to communities. The community members have lost trust in the government and municipal officials at Maswazini due to service delivery challenges. Therefore, this study recommends a thorough review, monitoring and evaluation of service delivery to improve the performance of Okhahlamba municipality.

Keywords: efficiency; effectiveness; local government; service delivery; policy.

\section{Introduction}

The purpose of this study is to examine service delivery challenges experienced by communities in the Okhahlamba Municipality. This study argues that the Okhahlamba Local Municipality has failed to provide effective and efficient services to the communities within its jurisdiction. Despite the policies and guidelines supporting service provision at Okhahlamba, the municipality is experiencing a backlog in service delivery. The intention of this study is to determine the strategies that can enhance municipal capacity and provide basic services in the same manner as in the urban towns and for cities' residents. The main responsibility of local government is to provide basic services, such as water, electricity, housing and proper sanitation. Marcus (2014:01) argues that there is 'urban bias in development' regarding the provision of services because development is skewed and occurs more in urban areas.

Scholars alluded to the capacity of municipalities, which is a perquisite for service provision in local government. Koma (2016) alluded to the state of local government and noted their limited capacity based on the unorganised infrastructure to enable them to provide services. On the other hand, Amtaika (2017) is of the view that local government's problem is orientated by the types of interventions that are not suitable to foster service delivery and development. Government is compelled to support rural development and support municipalities in implementing rural development projects in areas that are underserviced. In the 25 years of democratic governance, the government has been unsuccessful in the implementation of the strategic goals on rural development, even though the White Paper on Local Government (Republic of South Africa 
[RSA] 1998:27) authorises the local government to provide infrastructure and services for households.

South African local government honours the existence of national goals and strategic alliance of policy directives in the provision of basic services. One of the major national objectives is aimed at addressing problems such as poverty, inequality and unemployment. The national strategic alliance on strengthening the performance of the state gives direction to a missing link from the previous era and now; hence, there is a gap in what the communities need and what the municipalities offer. Sectors such as agriculture, social development, tourism, education, health, rural non-farm enterprises and others have dedicated themselves to provide assistance to redress the previously disadvantaged by providing goods and services to them (Local government budget expenditure review report 2011). According to the Department of Rural Development and Land Reform Review (DORDLR 2013), South Africa has managed to achieve and sustain impressive economic growth. It is apparent that the economic growth in South Africa is staggering. There are, however, some significant challenges the country is still facing. Progress in urban areas stands in stark contrast to the extreme level of poverty, which many South Africans in rural areas still endure. Social deprivation and underdevelopment continue to haunt many rural areas. This study investigates the challenges of service delivery by reviewing literature to establish the problem being investigated and by conducting an empirical study to examine these challenges from the local officials, DORDLR and the residents of the Maswazini settlement in the Okhahlamba Municipality.

\section{Background to the research problem}

This study assesses challenges of service delivery in the Maswazini rural area, with specific reference to housing, electricity, water and sanitation. Given the nature of local government, rural municipalities fall short in collecting revenue compared to the urban cities and district municipalities (Makale 2015:4). Wolff, Kühl and Satzger (2018:2) assert that the challenge of municipalities is to offer service delivery that is structured in a manner that optimises providers' costs and resources without considering the impact of costs associated with service quality and customer and community satisfaction. Martins and Ledimo (2015:575) also argue that inadequate capacity results in a greater need for service delivery innovations and technology that could help customers to access services. Makale (2015:1) identifies a backlog that causes slow service delivery improvement in rural areas. Also, rural areas are more vulnerable to service delivery inadequacy because of poverty and social exclusions (Pisani \& Sivini 2008). These alternative ways of providing services are often commonly used in urban areas rather than in rural areas. Based on the challenges of service delivery, municipalities like Maswazini are unable to sustain service delivery and address the gaps that are experienced by communities.
Since the inception of democracy, local government has been given a crucial and critical role to rebuild communities and environments based on promoting a non-sexist, non-racial society whilst improving the socio-economic status of people in different communities. Siddle and Koelble (2016) argue that the current state of local government is in contrast to their mandate to ensure that they provide services to communities. It is a dilemma to even compare the successes of municipal monitoring and auditing to effectiveness and efficiency. Khwela (2015) faults the success of a developmental state to the slow pace of transformation, which later resulted in municipalities being unable to realise the goals and targets they set. Some of the municipal faults are witnessed when development efforts planned to address poverty and inequality are silenced in the developmental state.

However, the slow pace of service delivery and activities in most municipalities in South Africa has failed to prove effective, particularly in the rural areas. Citizens are starting to lose confidence and trust in municipalities because of the failure of local government service delivery. Salaam (2016:6) agrees that there has been ineffective and inefficient service delivery in areas because of lack of funds, corruption, political interference, limited autonomy and poor capacity and skills. According to Salaam (2016), the leading factor that contributes to a lack of service delivery is the high degree of external influences from external parties in local government affairs. Although the autonomy of local government has been enhanced by self-governing legislative authority, municipalities are still interdependent on other spheres for support and supervision. National and provincial spheres supervise the extent to which municipalities exercise their powers and functions and cooperate with one another in order to promote the welfare objective of the entire country (Jure 2017).

Local government inferiority is evident from the fact that a municipality's right to govern its own initiatives is conditional in the sense that it is subject to national and provincial legislation and intervention (Singh 2016). Because local government has become the first point of contact between the citizens and government, municipalities in South Africa are broken down into three categories. The overall objective is to focus on enhancing local economies and providing adequate social and infrastructural services to those living in their jurisdiction (Alexander \& Berman 2014). The next section will focus on the policy framework for local government.

\section{The context of service provision}

The government emphasises on the significant role that municipalities should play in addressing backlogs in accessing basic services in rural areas, particularly the following as a focus of the study: municipalities are required to make sure that communities within their municipal areas are provided for and have access to adequate housing to ensure a safe and healthy environment. The Constitution of the Republic of the South Africa Act 108 of 1996 (RSA 1996) under the Bill of Rights chapter gives the right to every citizen to have adequate housing. However, Ross, Bowen and 
Lincoln (2010:433) reveal that millions of previously disadvantaged citizens of South Africa still live in informal settlements that lack proper shelter and other basic services.

Ross et al. (2010:433) continue to say that housing remains one of the most obvious infrastructure deficiencies in South Africa and the developing world. Another service offered by the municipality is water. Water is a natural resource and should be made available in a sustainable manner to all South Africans (RDP 1994:32). The Water Services Act 108 of 1997 (Republic of South Africa 1997) objective is to provide the right to access the supply of basic water services and sanitation facilities necessary to secure clean water and an environment that is not harmful to human health and wellbeing. The main role of municipalities, according to Mokonyane (2017) article, is the constitutional responsibility to provide adequate water and sanitation to all citizens. Municipalities are mandated by the Constitution of the Republic of South Africa Act 108 of 1996 (RSA 1996) to provide safe and clean water to their communities, and it further stipulates that the primary responsibility for the provision of water services lies with local government. Priority should be given to provision of water and proper sanitation in their strategic plans and should be included in their long-term integrated development plans. In support of municipalities in the implementation of water supply services, the national and provincial department of water and forestry plays a direct role in the provision of water supplies to local communities and implements programmes that aim to ensure that all South Africans have access to adequate portable water supply (Marcus \& Sulika 2006).

Rural and remote areas still struggle to gain access to electricity. People in rural areas depend on wood fires and dangerous chemicals to produce light. The publication on Sustainable Energy Africa (2014) reveals that, whilst South Africa may have strong policies on energy, despite the efforts, the country still struggles with high levels of insufficient energy 20 years into democracy. However, if the country is to address the issue of energy poverty and reach its goal of access to electricity, policies, regulations and resources in order to support energy service delivery, it needs to be reviewed constructively. The publication also confirmed that over 7 million households continue to rely on unsafe and unhealthy sources of energy, such as coal, biomass and paraffin (Sustainable Energy Africa 2014). The local government budget and expenditure review (2011) reports that electricity plays a significant role in the betterment of the lives of people. Apart from social benefits, it is also a factor that drives the economy, for instance, from communication to transportation. Section 153 of the Constitution (108 of 1996) points out that the role of the municipality is to provide services, including electricity reticulation, to communities in a sustainable manner in order to promote socio-economic development.

The Department for International Development (DFID) (2002) stated that energy can play a crucial role in underpinning efforts to achieve the Millennium Development Goals and improving the lives of poor people across the world. To implement the goal accepted by the international community, which was to halve the proportion of people living on $<1$ USD per day by 2015, access to affordable energy services was a prerequisite. The DFID (2002) further outlined that a lack of access to adequate, affordable, reliable, safe and environmentally benign energy is a severe constraint on development. The number of people without access, even to meet their basic needs, is staggering.

\section{Challenges of basic service delivery}

The provision of sustainable basic services to the public is a priority of the Constitution of South Africa. Some of the challenges identified from the literature review are discussed in the subsequent sections.

\section{Lack of access to basic service}

In the rural areas, there is inadequate access to basic services, particularly housing, electricity, water and sanitation. In communities, this poses major challenges in terms of the well-being of people and compromises the social and economic development. According to Momba et al. (2006:720), healthy drinking water is inadequate, and the water that is available is often of poor quality and cannot be considered safe. Regarding electricity, Barron and Torero (2014:1) argues that electricity alone cannot create all conditions of economic growth, but it is important for human needs and activities. Access to electricity improves socio-economic conditions through its influence on poverty, health, education and environment. Khandker et al. (2009) agree that a lack of access to energy and electricity is one of the major challenges in as far as economic development is concerned. According to Pueyo and Hanna (2015), lack of electricity hinders economic growth, as it is crucial for enterprises in terms of increasing productivity, income and employment whilst reducing workloads. However, electricity in poor communities is mainly used for lighting.

Sesani (2005:240) asserts that inadequate sanitation results in the utilisation of the bucket system, unimproved pit toilets and the bush. There is a growing number of poorly designed sewerage systems, and when these fail, they pose health challenges to the communities and pollution in the environment becomes extreme. Sanitation problems in South Africa are represented by inadequate excreta disposal facilities and unhygienic practices. These unhygienic practices are often related to a lack of access to health and hygiene education, a lack of water supply, poor sanitation facilities and inadequate domestic waste disposal facilities (Sesani 2005:24, 25).

Poor sanitation increases the spread of health problems. Many human infections are spread through inadequate sanitation. Viruses, bacteria, protozoa and worms may spread through direct contact or indirectly via carriers and vectors. The Water Service Act (RSA 1997:13) mentions that 
diarrhoea is the leading child killer disease in South African children. The white paper on basic household sanitation (RSA 2007) affirms that adequate basic household sanitation facilities can have dramatic health benefits on communities. It further highlights the effects of pollution, which include waterborne diseases, blue baby syndrome in bottle-fed infants, excessive growth of aquatic plants, which are toxic, and depletion of oxygen in the water. Regarding housing infrastructure, Govender, Barnes and Piepers (2011) outline that the strain imposed on municipal services by densification of unofficial backyard shacks often creates unintended health risks. Furthermore, the backlogs of housing are close to one-fifth of households living in informal settlements.

\section{Non-compliance with municipal policies}

Policy regulations in local government are understood to be the legal and administrative prescripts designed to guide municipal managers and local residents on how they can discharge their duties as expected. In the case where these policies are bridged because of non-compliance, municipalities compromise service delivery. In terms of the rule of law, the enforcement of these regulations and policies is to mandate and prohibit employers and employees from breaking the law and enable them to adopt certain actions (Financial and Fiscal Commission 2014). One of the major shortcomings that hinders service delivery is non-compliance with institutional policies and regulations that guide municipal employers and employees in the delivery of goods and services. Non-compliance by municipal officers is a threat and risk that instigate poor performance and inefficiency in public service (RSA 2017).

\section{Insufficient financial resources}

Local government, as the custodian of public funds, is tasked with the authority to use resources effectively to address the needs of the citizens for basic services, such as water, electricity, housing and sanitation (Kroukamp 2016:33). Edwards (2002) also argues that municipalities are confronted with a challenge of having insufficient budget that is needed to carry out necessary functions and provide services to the people. The financial challenge is attributed to various factors, such as non-payment of tax and municipal rates by residents, unethical practices, non-compliance with local government finance regulations and lack of skilled and competent personnel with necessary finance and computer skills to run finances effectively. The Institute for Democratic Alternative in South Africa (IDASA) report (2010:6) agrees with the fact that municipalities are associated with the worst form of financial mismanagement. Corruption, failure to provide clean audits and non-compliance with financial regulations are common elements that hinder service delivery and can result in poor performance and compromise the delivery of social services. According to Laubstler (2012:63), financial control is the most important aspect that determines the success and failure of local government. Financial mismanagement prevents progress, growth and development of municipalities and compromises honesty and integrity of local government.

\section{Lack of capacity}

In the context of this study, municipal capacity is the potential and competency of a municipality to perform whilst utilising its resources, technical and operational functions and competencies. Municipalities lack the capacity to develop and meet the needs and expectations of the people in as far as basic service delivery is concerned (Kroukamp 2016:43). The coordination of capacity building report issued by the department of Cooperative Government and Traditional Affairs (n.d.) presents that the lack of technical skills, knowledge, leadership and management within local government affects government. Officials and councillors lack basic skills and knowledge, and tools and resources to carry out necessary tasks and deliver services (IDASA 2010:9). Local government officials are closer to communities, hence they need resources to improve their problem of insufficient capacity to implement development programmes. As a result, the quantity and quality of service delivery are compromised (Chakunda \& Chakaipa 2015:2).

\section{Research methodology}

This section describes the methodology the researcher followed in the process of carrying out this study. The discussion includes the study design, research approach, area of study, population, sampling methods, data collection instruments, data analysis and limitations of the study. The researcher collected data for this research from September to December 2018, covering a period of 3 months. The focus area was in the Maswazini settlements, in the Okhahlamba Municipality and the DORDLR. The main language spoken in the Maswazini area is isiZulu. To overcome the language barrier in communicating with respondents, the researcher used the services of research assistants to translate and interpret English into isiZulu when gathering the data. The aim of this study is to critically examine challenges of service delivery in the Maswazini rural area, with specific reference to housing, electricity, water and sanitation.

The research study was conducted in the BergvilleMaswazini rural area (Kwa Smahla, Ward 14) under Inkosi Shabalala (traditional leader) and the Okhahlamba Local Municipality that forms part of the Uthukela District Municipality in KwaZulu-Natal. Bergville neighbours Ladysmith and Estcourt in Northern KwaZulu-Natal. Bergville has a population of 1067 million people, of which 7000 people reside in the Maswazini area (Statistics South Africa [STATS SA] 2011). A case study design was adopted and applied in this research. Bryman et al. (2014:110) agree that a case study gives a detailed and intensive analysis of single or more cases that the researcher aims to study. A mixed method approach was applied. Neuman (2012:42) mentions that most case study research is qualitative, but it 
does not have to be. By contrast, almost all cross-case (or non-case) research is quantitative. Therefore, a mixed method approach was suitable in that case studies are appropriate when conducting research in events where the objective is to study humans, systems, individuals, programmes and events. According to Creswel (2016:4), a mixed method research approach involves collecting both qualitative and quantitative data.

The sample size of the study comprised 235 participants, 200 being male and female residents of the Maswazini area, 20 municipal employees and 15 from DORDLR. Purposive sampling was carried out in this study. According to Maree (2017:84), a purposive sampling technique selects the sample by targeting particular categories of interest within the population. In this research study, interviews were conducted with the prominent Maswazini residents and municipal and department employees to gather information about the provision of basic services including electricity, housing, water and sanitation. Officials under the technical services department at the Okhahlamba Municipality and the DORDLR were interviewed. The next section will focus on the analysis of data and interpretation of findings.

\section{Data analysis and interpretation}

This section presents data analysis based on the responses of the respondents. Data were analysed using Excel and a thematic approach. Data analysis is presented as biographical information and thematic analysis that correspond to the research questions.

\section{Biographic details}

Table 1 shows that a total number of 231questionnaires were distributed among the experts from the Department of Land and Rural Affairs, officials from the Okhahlamba Municipality and members of the Maswazini community. Participants returned all 231 questionnaires.

\section{Participants' gender in the sample}

Table 2 presents the gender of participants from the community and the Department of Rural Development and municipal officials. Based on this sample, 117 were female

TABLE 1: Sampling and distribution of questionnaires.

\begin{tabular}{lcccc}
\hline Variable & Distributed & Returned & Spoilt & Analysed \\
\hline Experts & 10 & 10 & 0 & 10 \\
Officials & 20 & 20 & 0 & 20 \\
Okhahlamba residents & 201 & 201 & 0 & 201 \\
\hline Total & $\mathbf{2 3 1}$ & $\mathbf{2 3 1}$ & $\mathbf{0}$ & $\mathbf{2 3 1}$ \\
\hline
\end{tabular}

TABLE 2: Participants' gender.

\begin{tabular}{lcccc}
\hline Gender & Residents & Officials & Experts & Total \\
\hline Female & 100 & 10 & 7 & 117 \\
Male & 101 & 10 & 8 & 119 \\
\hline Total & $\mathbf{2 0 1}$ & $\mathbf{2 0}$ & $\mathbf{1 5}$ & $\mathbf{2 3 6}$ \\
\hline
\end{tabular}

and 119 were male respondents. The table reflects a frequency whereby male participants outweigh female participants.

\section{Ages of participants in the study}

Table 3 indicates the age group of participants. The majority of participants, $46.8 \%$, were between the ages of 36 and 55 years, whilst $35.3 \%$ were between 25 and 35 years. Participants between the age of 21 and 25 years formed $11.9 \%$ of the sample, and $6 \%$ were over the age of 55 years. The results indicate that mostly adults participated in the study.

\section{Participants' race}

The results of the survey show that the majority of participants $(99 \%)$ were black people followed by $0.5 \%$ white people and $0.5 \%$ Asians. The survey indicates that the majority of respondents were black people (Table 4).

Figure 1 illustrates the number of years lived by people at Okhahlamba. The majority of respondents (39.3\%) have been in the Maswazini area for 26-35 years followed by $28.9 \%$ of the respondents who have stayed in the area for 11-25 years. Furthermore, $24.9 \%$ of the respondents have stayed for over 35 years and $7 \%$ have been in the area for $<10$ years. The reason why the respondents were asked how long they had been staying at the Maswazini rural area was to assess their presence in the development and provision of services in and around area.

\section{Service delivery challenges at Okhahlamba}

The findings of the research study revealed that the challenges of service delivery in local government are still observed after 26 years of democracy. The analysis of the data findings showed that the lack of water, sanitation,

TABLE 3: Participants' age.

\begin{tabular}{lccccc}
\hline Variable & $\begin{array}{c}\text { Residents' } \\
\text { age }\end{array}$ & Frequency & $\mathbf{\%}$ & $\begin{array}{c}\text { Valid } \\
\mathbf{( \% )}\end{array}$ & $\begin{array}{c}\text { Cumulative } \\
(\mathbf{\%})\end{array}$ \\
\hline Valid & $21-25$ & 24 & 11.9 & 11.9 & 11.9 \\
& $26-35$ & 71 & 35.3 & 35.3 & 47.3 \\
& $36-55$ & 94 & 46.8 & 46.8 & 94.0 \\
& $>55$ & 12 & 6.0 & 6.0 & 100.0 \\
& Total & 201 & 100.0 & 100.0 & - \\
Municipal & $26-35$ & 8 & 40.0 & 40.0 & 40.0 \\
officials & $36-55$ & 12 & 60.0 & 60.0 & 100.0 \\
& Total & 20 & 100.0 & 100.0 & - \\
Experts & $26-35$ & 10 & 66.7 & 66.7 & 66.7 \\
& $36-55$ & 5 & 33.3 & 33.3 & 100.0 \\
& Total & - & - & - & 100.0 \\
\hline
\end{tabular}

TABLE 4: Race.

\begin{tabular}{llcccc}
\hline Variable & Residents & Frequency & $\mathbf{\%}$ & $\begin{array}{c}\text { Valid } \\
(\mathbf{\%})\end{array}$ & $\begin{array}{c}\text { Cumulative } \\
(\mathbf{\%})\end{array}$ \\
\hline Valid & White people & 1 & 0.5 & 0.5 & 0.5 \\
& African people & 199 & 99.0 & 99.0 & 99.5 \\
& Asian people & 1 & 0.5 & 0.5 & 100.0 \\
& Total & 201 & 100.0 & 100.0 & - \\
$\begin{array}{l}\text { Municipal } \\
\text { officials }\end{array}$ & African people & 20 & 100.0 & 100.0 & - \\
Experts & African people & 15 & 100.0 & 100.0 & - \\
\hline
\end{tabular}




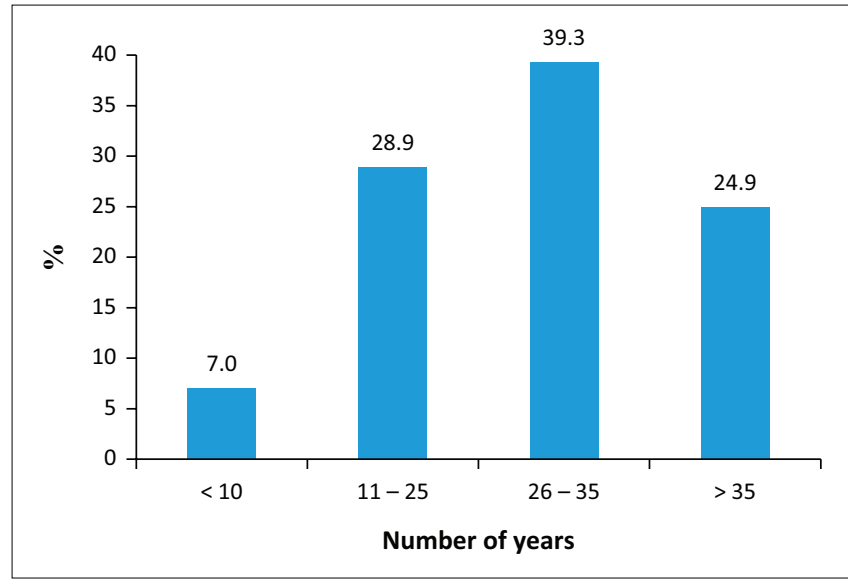

FIGURE 1: Number of years one lived in Okhahlamba municipal area.

electricity and housing in Maswazini compromises the productivity and well-being of the people and poses a threat to their health. There are little to no basic services in the Maswazini area, and the little water that the community relies on is inadequate, unsafe and barely accessible. Proper sanitation is insufficient as the community is more reliant on their self-built toilets. The DORDLR did not succeed in providing proper housing infrastructure, although there is vacant land that was purchased by them. The electricity has been recently installed in some parts of the area and yet others do not have access. This again raises an issue of inequality and biasness. Okhahlamba is not immune to service delivery challenges. One of the participants indicated their challenges when he said:

'In order for the department to communicate with the community, there is a Chairperson of the Trust, which is our central stakeholder that represents us as the department.' (Community leader, Maswazini, 02 September 2018)

According to the respondents, there is no proper planned platform for public participation to enhance public service delivery at Okhahlamba. The main factors that hinder the processes of service delivery are mostly internal strategic and operational. The findings indicated that the Okhahlamba Municipality does not provide enough services across the entire community of Maswazini. This is because of a lack of financial and other limited resources, political influence and decision-making, a lack of community involvement until there is a crisis and too many parties and stakeholders with their own interests that get involved in the formulation and implementation of service delivery projects and programmes.

The researcher found that the state of rural development is slow in Maswazini and the residents have accepted their standard of living. Meanwhile, on the side of service providers, being the Okhahlamba Local Municipality and the DORDLR, the efforts and interventions in the provision of service delivery are observed. Change is evident in terms of service delivery compared to pre-1994; however, some services are delayed or not delivered at all because of institutional factors that threaten the delivery of services as mentioned earlier. Another factor that poses a challenge is monitoring and evaluating the services delivered by the municipality. The findings showed that Maswazini still uses the old system of access to water services and sanitation. This revealed that there is a pronounced lack of evaluation to determine whether the plans and systems that are used are still relevant or whether they need to be upgraded and maintained. Alluding on service delivery challenges, one respondent said:

'There are a number of challenges, one of them being Maswazini consisting of a large population with different issues such as political issues. Political parties bring their own interest, political driven views and ideas to service delivery gatherings, which then makes it difficult for the department to continue with the smooth operation and implementation of programmes.' (Community member 1, Maswazini, 02 September 2018)

Literature indicates that despite government's developmental plans and interventions since 1994, a large population continues to live in poverty. The findings from the study indicate that large parts of the world's poor are rural communities. Poverty and social exclusion are more evident in the rural areas. Development and service delivery are better observed in urban areas with developed infrastructure and human settlement. However, this disparity has led to imbalance and inequality regarding the provision of basic services. Koma (2010:114) highlighted that some areas have significantly improved in terms of development according to their plans and other areas still require more efforts with the view to improve. The current state of local government in rural areas shows that most rural municipalities are still faced with basic service delivery backlogs.

\section{The status of service delivery in the Maswazini rural area}

The study and findings revealed that there are limited basic services in the area, but despite the efforts made by the Okhahlamba Municipality, these services are inadequate. There is a shortage of water supply and lack of sanitation and housing infrastructure, and some parts of the area do not have electricity. The Maswazini residents do not receive enough services, and the area is underdeveloped. The majority of residents are not satisfied with the supply of basic services by the Okhahlamba Local Municipality. The shortage of basic services in the area has greatly affected several households, especially where insufficient water and proper sanitation are a concern. It was revealed that there are no toilets, and the residents walk long distances to fetch water. Electricity has been installed in some parts of Maswazini, but not across the entire area. Only a few households have benefited from it, and in terms of houses, the community has never received housing infrastructure. One of the respondents commented on the status of service delivery at Okhahlamba and said:

'I can say that the community of Maswazini is happy but not fully satisfied, because they have the land, but the issue of 


\begin{tabular}{|c|c|c|c|c|}
\hline \multirow[t]{2}{*}{ Responses } & \multicolumn{4}{|c|}{ Frequency (10 responses) } \\
\hline & Strongly agree & Agree & Neutral & Disagree \\
\hline \multicolumn{5}{|l|}{ Challenges observed by community members } \\
\hline 1. The municipality and the DORDLR render adequate services in the Maswazini rural areas. & - & 17 & 17 & 164 \\
\hline 2. The municipality provides adequate and efficient water, electricity, housing and sanitation. & - & 9 & 35 & 126 \\
\hline 3. I can easily access services from municipality. & - & 10 & 33 & 129 \\
\hline 4. There are challenges that the community encounters regarding electricity, housing, water and sanitation. & 38 & 144 & 13 & 3 \\
\hline 5. We have tried to address the challenges with the municipality. & 47 & 150 & 2 & 1 \\
\hline 6. The municipality responds to those challenges. & 6 & 8 & 50 & 104 \\
\hline 7. The municipality consults or informs the Maswazini residents regarding the provision of services. & 7 & 51 & 67 & 34 \\
\hline 8. There is a gap between what we want and what is offered at the Maswazini municipality. & 102 & 95 & 1 & 1 \\
\hline 9. The Maswazini community are happy and satisfied with the service delivery in the area. & 1 & & 50 & 149 \\
\hline 10. The state of rural development has improved over the years. & - & 2 & 86 & 110 \\
\hline \multicolumn{5}{|l|}{ Challenges observed by Municipal officials } \\
\hline 1. The municipality renders enough services in the Maswazini rural areas. & 2 & 16 & - & 2 \\
\hline 3. The services are easily accessible to the people. & 4 & 13 & - & - \\
\hline 4. Does the municipality provide good quality electricity, housing, water and sanitation? & 3 & 15 & 4 & - \\
\hline 5. There are challenges that the municipality encounters when delivering services. & 2 & 11 & 2 & 4 \\
\hline 6. The municipality consults the Maswazini residents regarding the provision of services. & 6 & 14 & - & - \\
\hline 7. There is continuous monitoring and evaluation of services by the municipality. & 5 & 6 & 5 & 3 \\
\hline $\begin{array}{l}\text { 8. In our perspective, the Maswazini community is happy and satisfied with the provision of water, electricity, } \\
\text { housing and sanitation. }\end{array}$ & - & 8 & 10 & 2 \\
\hline 9. The municipality is committed to providing best services to the Maswazini community. & 5 & 12 & 3 & - \\
\hline 10. The state of rural development has improved over the years. & - & 6 & 10 & 2 \\
\hline \multicolumn{5}{|l|}{ Challenges observed by experts in rural development } \\
\hline 1. The DORDLR render enough services in the Maswazini rural areas. & - & 2 & - & 13 \\
\hline 2. There are rural development projects/programmes implemented by the department in Maswazini. & - & 14 & - & 1 \\
\hline 3. The Maswazini community benefits from those programmes. & - & 13 & - & 1 \\
\hline 4. There are challenges that the department encounters pertaining to service delivery. & 15 & - & - & - \\
\hline 5. The department consults with the Maswazini community regarding the provision of services. & - & - & - & - \\
\hline
\end{tabular}

DORDLR, department of rural development and land reform.

making the land operate for their own benefit is still a challenge, for example, creating projects to be implemented on the land that was acquired by the department. The development of the land has not happened. The community is dissatisfied with the status of service delivery and nondevelopment of the land purchased.' (Community action group member, Maswazini, 02 September 2018)

Fourie and Poggenpoel (2016:171) observe that government has had an impressive achievement since 1994 but poverty, inequality and unemployment remain a major challenge in rural areas as they are still associated with underdevelopment and poor social conditions. Table 5 indicate that Okhahlamba Municipality and the DORDLR have made efforts to delivery services to the community, even though some processes and service delivery projects were not consolidated.

\section{The accessibility and availability of services}

Access to services is an issue. Some respondents indicated that they have no access to services because of insufficient financial resources and lack of transport to reach service points. Some of the municipal officials were not reluctant to agree that their municipalities do not receive enough rates from residents; hence, they do not have enough resources to provide services. Based on the perceptions of the residents, it was found that housing, water and sanitation services are not accessible to the area. Residents spend months and months without clean and safe water, and they use their self-built toilets, which are dangerous to their health and well-being. In other circumstances, the municipality does not maintain their service delivery systems as the Maswazini area still uses the old water supply system and boreholes, which is one of the reasons for the lack of distribution of water. A participant indicated that:

'The current state of accessibility of services in our area is depressing as we do not have water, we rely on water from the river which we have to walk miles to fetch them. We mostly rely on self-made toilets and this was brought to the attention of the government, Okhahlamba Municipality to be precise. The promised to do something about it but till today nothing has happened. We are expecting to have taps in our yards, and we will continue to wait on them.' (Beneficiary of development programme, NDORD, 02 Sepember 2018)

According to Johannes and Erasmus (2016:180), lack of basic services in the rural areas is still observed and the responsibility lies with the local government to ensure that communities have equitable access to municipal service. Furthermore, the Constitution further obligates local government, as the sphere that is closer to the people, to be responsible for the provision of good quality services to improve the standard and quality of life of the people, whilst addressing socio-economic challenges in the country. 


\section{Methods for community engagement}

Community involvement is a crucial concept in service delivery as it provides a platform for communities to have input in planning and decision-making concerning service delivery. The findings revealed that the visibility of the municipality is minimal. The engagement between the municipality and the community occurs only when there is an urgent need, where the municipality would call community meetings and the Integrated Development Planning (IDP) road shows. According to Madzivhandila and Asha (2012:373), community members must be considered as key role players in local development processes. Structures of community participation create conditions where communities have a strong role in developing strategies and can make inputs and influence decisionmaking and identification of their needs as beneficiaries of municipal services. One respondent testified about their participation on community issues and said:

'Municipality and the department call out community meetings through the local councillor and traditional leaders when there is a need for community engagement and consultation.' (Community member 2, Maswazini, 02 September 2018)

In addition, there is minimum representation of the community in these meetings. People have become reluctant to attend community meetings. This study shows that there is no constant communication between the Maswazini community, municipality and the DORDLR. A respondent commented by saying:

'Municipal officials have engaged with the community in most of priorities on service delivery at Okhahlamba, especially when when we seek their help and they need assistance, we are still going to improve our respond timely, as it should not take long to respond. Community needs must come first and must be addressed in an equal manner that benefits everyone in and around the area. Also, the Maswazini community should work hand-in-hand with government because we are all in this together.' (Municipal official, Maswazini, 02 September 2018)

\section{Conclusion}

This study demonstrated that Okhahlamba Municipality struggles to attain its goals that focus on enhancing service delivery because of enormous challenges affecting the municipality and communities. There are challenges that inhibit the municipality from achieving its aim of providing effective and efficient service delivery to communities. This study revealed that the status of service delivery at Okhahlamba is not satisfactory, and the community members cannot access all services as they need. Access to service points is a problem at Okhahlamba, especially in rural villages where there is no stable transport for community members to access service points. Community members do not feel valued by municipality because they are not invited to engage fully in decisions affecting their communities, such as operational matters and service delivery activities. Residents revealed that there were shortages in service delivery in areas such as housing, water and sanitation services, which are not accessible to residents in that area. Based on the findings, the Okhahlamba Municipality provides services to the residents with limited success. However, the residents are not satisfied with the performance of the municipal officials, and they lost trust in the government.

\section{Recommendations}

This article suggests that that municipality of Okhahlamba must make sure that community members experience a positive impact towards service delivery. They need to be responsive to community needs and develop better relations with the communities to win their trust.

Municipalities must realise that the needs of the people come first, and they must deliver as they promise. If not, communities must be informed about changes that affect service delivery and how they can be addressed.

Municipal officials must be accountable to the public and to their counterparts. They must foster quality circles for improvement and engage all the civil servants responsible for service provision through various strategies of public participation. They must offer training and workshops to improve their knowledge on practical strategies to enhance service provision.

It is imperative that all public servants comply with policies and legislation related to their work and ensure that they do not support any act of misconduct and mismanagement of resources. Also, communities must participate and contribute ideas on the roll-out of municipal planning that leads to addressing community needs in a proper manner that complies with the Constitution (RSA 1996) and municipal laws. In addition, municipal officials must empower community members with knowledge of diverse aspects that affect and encourage them to attend public hearings and various platforms to improve development in their communities.

\section{Acknowledgements Competing interests}

The authors have declared that no competing interest exist.

\section{Authors' contributions}

The authors contributed equally to this work.

\section{Ethical consideration}

The study was granted ethical clearance by the university ethics committee at Durban University of Technology. The permission for access was granted by the municipality of Okhahlamba.

\section{Funding information}

The authors thank Durban University of Technology for the payment of page fees. 


\section{Data availability}

The authors confirm that the data supporting the findings of this study are available within the article.

\section{Disclaimer}

The views and opinions expressed in this article are those of the authors and do not reflect the official policy of any affiliated agency of the authors.

\section{References}

African National Congress, 1994, Reconstruction development plan, African National Congress, Johannesburg.

Alexander, G. \& Berman, J., 2014, The 80/20 report: Local government in 80 indicators after 20 years of democracy, South African Institute of Race Relations, Cape Town.

Amtaika, A. (ed.), 2017, Socio-economic development in Africa: Challenges and dimensions, Pan-African University Press, Austin, TX.

Barron, M. \& Torero, M., 2014, 'Electrification and Time Allocation: Experimental Evidence from Northern El Salvador', MPRA Paper 63782, University Library of Munich, Munich.

Bryman, A., Bell, E., Dos Santos, A., Du Toit, J., Masenge, A., Van Aardt. et al., 2014, Research methodology: Business and management context, Oxford University, Cape Town

Chakunda, V. \& Chakaipa, S., 2015, 'Local government capacity building and development: Lessons, challenges and opportunities', Journal of Political Science and Public Affairs 3(1), 1-5. https://doi.org/10.4172/2332-0761.1000149

Cooperative Governance and Traditional Affairs, n.d., Coordination of capacity building in local government, Cooperative Governance and Traditional Affairs, Pretoria.

Creswel, J.W., 2016, Research design: Qualitative, quantitative, and mixed method approaches, Sage, London.

Department of International Development, 2012, Department for International Development Annual Report and Accounts 2011 - 2012, United Nations Children's Fund (UNICEF), London.

Department of Rural Development and Land Reform (DORDLR), 2013, Rural development framework policy, viewed 26 September 2018, from www. ruraldevelopment.go.za/legislation-and-policies/file/2093.

Edwards, J.D., 2002, 'IT and I ocal government: Addressing the financial challenges facing South African municipalities', Institute of Municipal Finance Officers 3(2), 12

Financial and Fiscal Commission, 2014, Annual report: For equitable sharing of national revenue, Financial and Fiscal Commission, Johannesburg.

Fourie, D. \& Poggenpoel, W., 2016, 'Public sector inefficiencies: Are we addressing the root causes', South African Journal of Accounting Research Financial and Fiscal Commission 31(3), 169-180. https://doi.org/10.1080/10291954.2016.11 60197

Govender, T., Barnes, J. \& Piepers, C., 2011, The impact of densification by means of informal shacks in the backyards of low-cost houses on the environment and service delivery in Cape Town, South Africa, viewed 27 October 2016, from https:// www.ncbi.nlm.nih.gov/pmc/articles/PMC3115642/.

Institute for Democratic Alternatives in South Africa, 2010, The state of local government and service delivery in South Africa: Issues, challenges, and solutions, Department of Cooperative Governance and Traditional Affairs, Pretoria.

Johannes, L. \& Erasmus, B., 2016, Service delivery challenges facing municipalities: $A$ case study of Fetakgomo Local Municipality, Limpopo Province, University of Limpopo, Turfloop.

Jure, D., 2017, 'Intrusion into the autonomy of South African local government: Advancing minority judgement in the Mmerafong city case', Journal of Public Administration 50(2), 324-345.

Koma, S.B., 2010, State of local government in South Africa: Issues, trends and options, University of Pretoria, Pretoria.

Khandker, S.R., Barnes, D.F., Samad, H. \& Minh, N.H., 2009, 'Welfare impacts of rural electrification: Evidence from Vietnam', Policy Research Working Paper Series 5057, The World Bank, Hanoi.
Khwela, N., 2015, 'Ensnarement of prisoner's families to poverty and crime in South Africa: A case of Polokwane medium B prison', unpublished PhD thesis, University of Limpopo, Polokwane.

Koma, S.B., 2016, 'Rationalisation of municipalities: A panacea for improved municipal governance in South Africa?', African Journal of Public Affairs 9(2), 127-139.

Kroukamp, H., 2016, Sustainable governance: The solution to the South African local government service delivery problems, University of Free State, Free State.

Laubstler, L.H., 2012, 'Challenges on financial control and accountability in South African municipalities', Journal for New Generation Sciences 10(1), 63-79.

Madzivhandila, T.S., 2012, Integrated development planning process and service delivery challenges for South Africa's local municipalities, University of Limpopo, Polokwane.

Makale, T., 2015, Service delivery in South African rural municipalities, Stellenbosch University, Stellenbosch.

Marcus, A., 2014, Urban poverty and rural development bias, SAGE publications, London.

Marcus, A. \& Sulika, A., 2006, 'Urban poverty and rural development bias', Journal of Developing Society 22(2), 145-168. https://doi.org/10.1177/0169796X06065800

Maree, K., 2017, First steps in research, 2nd edn., Van Schaik Publishers, Pretoria.

Mokonyane, N., 2017, Municipalities must play their part in water provision, viewed 08 March 2019, from http://www.iol.co.za/news/opinion/municipality-mustplay-their-part-in-water-provision-12234503.

Momba, N.M.B., Tyafa, Z., Makala, N., Brouckaert, B.M. \& Obi, C.L., 2006, Safe drinking water until a dream in rural areas of South Africa: Case study: The Eastern Cape province, Tshwane University of Technology, Pretoria.

National Treasury, 2011, Local budget expenditure review report: Rural services, National Treasury, Pretoria.

Neuman, W.L., 2012, Social research methods, qualitative and quantitative approaches, 7th edn., Pearson Education, Boston, MA.

Pisani, E. \& Sivini, S., 2008, Poverty and social exclusion in rural areas, European Commission, Brussels.

Pueyo, A. \& Hanna, R. 2015, What level of electricity access is required to enable and sustain poverty reduction? Institute of Development Studies, Bourton-on-the-Water.

Republic of South Africa, 1996, The Constitution of the Republic of South Africa Act 108 of 1996, Government Printer, Pretoria.

Republic of South Africa, 1997, Water services Act 108 of 1997, Government Printer, Pretoria.

Republic of South Africa, 1998, White paper on local government 1998, Government Printer, Pretoria.

Republic of South Africa, 2007, The White Paper on basic household sanitation, Government Printers, Pretoria.

Republic of South Africa, 2015, Annual year Report 2014/2015, Financial and Fiscal Commission, Pretoria.

Republic of South Africa, 2017, Auditor General of South Africa Report 2017, The Office of the Auditor General in South Africa, Pretoria.

Ross, N., Bowen, P. \& Lincoln, D., 2010, 'Sustainable housing for low-income communities: Lessons for South Africa in local and other developing world cases', Journal of Construction Management and Economics 28(5), 433-449. https://doi. org/10.1080/01446190903450079

Salaam, R., 2016, Appraisal of local government autonomy on service delivery at the grassroots in Nigeria, viewed n.d., from http://www.ciando.com/img/books/ extract/3668578311_lp.pdf

Sesani, T.F., 2005, An investigation of the level of sanitation in Bushbuckridge local municipality, Turflop School of Leadership, University of Limpopo, Polokwane.

Siddle, A. \& Koelble, T.A., 2016, Local government in South Africa, Swedish International Centre for Local Democracy, Visby.

Singh, A., 2016, Municipal representation as a mechanism to enhance local government efficiency: The role of association for local government authorities, University of South Africa, Pretoria.

South Africa, 2000, Municipal systems Act 32 of 2000, Government Printer, Pretoria.

Statistics South Africa (STATS SA), 2011, The Under five mortality rate: Findings from Census 2011 and other data sources, Statistics South Africa, Cape Town.

Sustainable Energy Africa, 2014, Tackling urban energy poverty in South Africa, Sustainable Energy Africa, Cape Town.

Wolff, C., Kühl, N. \& Satzger, G., 2018, 'System-oriented service delivery: The application of service system engineering to service delivery', in European conference on information systems 2018, Portsmouth September 09, 2018. 